\title{
A STUDY ON THE KNOWLEDGE, ATTITUDE, AND PRACTICES REGARDING VOLUNTARY NON- REMUNERATED DONATION OF BLOOD AMONG SECONDARY SCHOOL TEACHERS IN TAMILNADU
}

\author{
1Associate Professor, Department of Pathology, Tagore Medical College and Hospital. \\ ${ }^{2}$ Associate Professor, Department of Pathology, Tagore Medical College and Hospital. \\ 3 Professor and HOD, Department of Pathology, Tagore Medical College and Hospital. \\ ${ }^{4}$ CRRI, Tagore Medical College and Hospital. \\ ${ }^{5} 3^{\text {rd }}$ Year MBBS Student, Tagore Medical College and Hospital.
}

Jamunarani Srirangaramasamy¹, C. P. Luck², Madasamy Balamurugan³, Karthick Subash Selvaraju4, Ramya Mayakrishnan ${ }^{5}$

ABSTRACT

\section{BACKGROUND}

The aim of this study is to assess the level of awareness on blood donation among the secondary school teachers by ascertaining the level of knowledge, attitude and practices toward blood donation. In this regard, measures to fill the deficit would be sugge sted, if any discrepancies are found.

\section{MATERIALS AND METHODS}

This was a cross sectional study done in department of blood bank, Tagore medical college and Hospital. The study population were secondary school teachers from three higher schools in Tamil Nadu, India. A total of 109 teachers participated in the study. Questions regarding the knowledge, attitude and practices towards donating blood were prepared and questionnaires were distributed to the study population and their responses were analysed.

\section{RESULTS}

A total of 109 teachers participated in the study. 82.6\% of the teachers have never donated blood. The most common reason for not donating blood is no one has asked them to do so. The teachers had a good knowledge and a positive attitude towards blood donation. However, the practice of blood donation is very poor among teachers. $96.3 \%$ teachers assured to motivate the students and $81.7 \%$ were willing to donate blood in future.

\section{CONCLUSION}

The teachers in our study had adequate knowledge and a positive attitude towards voluntary donation of blood. However, practice on blood donation is very poor. This could be due to the lack of opportunity for blood donation and communication gap between the blood banks and the school teachers. Hence there must be a system to create opportunities for blood donation and measures to bridge the communication gap so that more donors would be volunteering to donate blood.

\section{KEYWORDS}

Voluntary Blood Donation, KAP on Blood Donation, Secondary School Teachers, Blood Transfusion.

HOW TO CITE THIS ARTICLE: Srirangaramasamy J, Luck CP, Balamurugan M, et al. A study on the knowledge, attitude, and practices regarding voluntary non-remunerated donation of blood among secondary school teachers in Tamilnadu. J. Evolution Med. Dent. Sci. 2017;6(10):786-789, DOI: 10.14260/Jemds/2017/170

\section{BACKGROUND}

Blood transfusion saves many lives. The demand for blood in India, a lower middle income country is high. This is due to increased incidence of pregnancy related complications and severe anaemia in children under 5 years of age. ${ }^{1}$ Till date, there are no satisfactory blood substitutes available. Since 1628, when William Harvey discovered the circulation of blood, many centuries passed without replaceable blood alternatives.

\section{Financial or Other, Competing Interest: None}

Submission 24-12-2016, Peer Review 19-01-2017,

Acceptance 25-01-2017, Published 02-02-2017.

Corresponding Author:

Dr. Jamunarani Srirangaramasamy,

Associate Professor,

Department of Pathology,

Tagore Medical College and Hospital

Rathinamangalam,

Chennai-600 127

Tamilnadu, India.

E-mail: jamunapath@tagoremch.com

DOI: $10.14260 /$ jemds $/ 2017 / 170$
According to WHO, 112.5 million blood donations are collected globally, out of which $50 \%$ of the blood donations are from high income countries. ${ }^{1}$ India, being a lower middle income country, there are only 4.6 blood donations per 1000 people. ${ }^{1}$ But the supply of blood is very short mainly due to lack of awareness and apprehensions about donation. ${ }^{2}$ The constant concern in the effort to meet the demands for blood is the fact that only a small percentage of eligible population actually choose to donate blood on a regular basis and that a significant number of eligible donors are deferred temporarily or permanently because of strict deferral criteria being practiced to ensure blood safety. ${ }^{3}$ In order to ensure safe blood donation, the government of India adopted the National Blood Policy in April 2002 to ensure easy access to adequate and safe blood.4 It is a well-established fact that blood collected from regular voluntary non remunerated blood donors are the safest. However, in India, replacement donors constitute more than $45 \%$ of the blood donors. 5

In creating awareness to the general public, the mass media has to play a major role. ${ }^{6}$ However, in creating the awareness in the long term, the young minds of the school children need to be instilled with the benefits of donation and 
the virtues of nobility towards the society they thrive, on donating blood. Teachers play a vital role in making the students imbibe these 'lessons for life'. For this to occur, the teachers must have a good knowledge, a cheerful attitude and the habit of being a regular, voluntary blood donor. Donor deferral can also be overcome by teaching the students not to indulge in activities that would lead to deferral. The most common reason for people not to donate blood in India is the counterargument that they were not asked by anyone to do so. ${ }^{6}$ This being the case in a highly populous country, the idea of this study is to shift the emphasis towards teachers on explaining the students about the importance of donating blood and thereby saving life.

\section{MATERIALS AND METHODS}

This was a cross sectional study carried out at department of blood bank, Tagore medical college and Hospital between March to July 2015. The study was approved by the Ethical Committee of the institution. The study population were secondary school teachers from three government schools in Tamil Nadu, India. A total of 109 teachers participated in the study. Teachers who have been qualified with at least an undergraduate degree in teaching and taking classes for students of $9^{\text {th }}$ to $12^{\text {th }}$ standards were included in the study. Retired teachers were excluded from the study as the purpose of the study is to motivate the students on voluntary blood donation.

A pre-formed, pre-tested and structured questionnaire, conveying consent was used. Their socio demographic profile, educational qualification and other relevant data was sought in the first part of the questionnaire. The second part contained specific questions regarding the knowledge, attitude and practices of donating blood. Questionnaires were distributed to the study population. Participants willing to participate were asked to sign the consent form, which was present in the questionnaire. Participants were informed about the privilege to leave the study at any point of time. Thus, the consent obtained was free, voluntary, direct, informed, written and personal. They were encouraged to fill the questions with the best of their knowledge. Sufficient time was provided for them to complete. The queries were clarified as and when required. While collecting and storing the data, utmost care was taken to maintain confidentiality.

The data obtained was entered in MS Office Excel 2007. The data analysis was done using SPSS software.

\section{OBSERVATION AND RESULTS}

A total of 109 teachers participated in the study. Out of 109, 79 were females and 30 were males. The median age of the study population was 39 years. The most common blood group in our study is $0+v e$. The prevalence of various blood groups among the study population is summarized in table 1 .

\begin{tabular}{|c|c|c|}
\hline Sl. No. & Blood Group & No. of Participants \\
\hline 1 & $0+v e$ & 43 \\
\hline 2 & $A+v e$ & 18 \\
\hline 3 & $B+v e$ & 34 \\
\hline 4 & $A B+v e$ & 08 \\
\hline 5 & O-ve & 00 \\
\hline 6 & A-ve & 02 \\
\hline 7 & B-ve & 02 \\
\hline 8 & AB-ve & 02 \\
\hline & Total & 109 \\
\hline \multicolumn{3}{|c|}{$\begin{array}{l}\text { Table 1. The prevalence of ABO blood } \\
\text { groups among the study population }\end{array}$} \\
\hline
\end{tabular}

Only 19 teachers $(17.4 \%)$ have donated blood already. The rest ( 90 teachers, $82.6 \%$ ) have never donated blood. Out of 19 donors, 18 donated only once and only one male teacher has donated 4 times. Hence $94.7 \%$ of the donors in our study were first time donors in our study.

The knowledge was evaluated by a set of 10 questions. $74.3 \%$ knew the minimum age to donate blood and $77.1 \%$ knew the minimum weight for blood donation. $97.2 \%$ said there are no ill effects to the donor and $85.3 \%$ were aware that they will not become anaemic after blood donation. Only 55\% knew the minimum interval between two donations and $34.9 \%$ knew the duration of actual blood donation. The awareness on the mandatory infections to be screened is poor except HIV which $82.6 \%$ of the respondents were aware of. The knowledge on blood donation was summarized in table 2 .

\begin{tabular}{|c|c|c|c|c|}
\hline $\begin{array}{r}\text { Sl. } \\
\text { No. }\end{array}$ & $\begin{array}{c}\text { Questions } \\
\text { Assessing } \\
\text { Knowledge on } \\
\text { Blood Donation }\end{array}$ & Response & $\begin{array}{c}\text { No. of } \\
\text { Respon- } \\
\text { dents }\end{array}$ & $\%$ \\
\hline \multirow{3}{*}{1} & \multirow{3}{*}{$\begin{array}{l}\text { Minimum age to } \\
\text { donate blood }\end{array}$} & Correct & 81 & 74.3 \\
\hline & & Incorrect & 25 & 22.9 \\
\hline & & Don't know & 3 & 2.8 \\
\hline \multirow{3}{*}{2} & \multirow{3}{*}{$\begin{array}{l}\text { Minimum weight } \\
\text { for donating blood }\end{array}$} & Correct & 84 & 77.1 \\
\hline & & Incorrect & 21 & 19.3 \\
\hline & & Don't know & 4 & 3.6 \\
\hline \multirow{3}{*}{3} & \multirow{3}{*}{$\begin{array}{l}\text { Blood is collected } \\
\text { from? Vein/artery }\end{array}$} & Correct & 82 & 75.3 \\
\hline & & Incorrect & 25 & 22.9 \\
\hline & & Don't know & 2 & 1.8 \\
\hline \multirow{3}{*}{4} & \multirow{3}{*}{$\begin{array}{l}\text { Are there any ill } \\
\text { effects to donor? } \\
\text { Yes/No }\end{array}$} & Correct & 106 & 97.2 \\
\hline & & Incorrect & 2 & 1.8 \\
\hline & & Don't know & 1 & 0.9 \\
\hline \multirow{3}{*}{5} & \multirow{3}{*}{$\begin{array}{l}\text { Will you become } \\
\text { anemic after } \\
\text { donation? Yes/No }\end{array}$} & Correct & 93 & 85.3 \\
\hline & & Incorrect & 16 & 14.7 \\
\hline & & Don't know & 0 & 0 \\
\hline \multirow{3}{*}{6} & \multirow{3}{*}{$\begin{array}{c}\text { Volume of blood } \\
\text { taken from donor in } \\
\text { one sitting }\end{array}$} & Correct & 79 & 72.4 \\
\hline & & Incorrect & 27 & 24.8 \\
\hline & & Don't know & 3 & 2.8 \\
\hline \multirow{3}{*}{7} & \multirow{3}{*}{$\begin{array}{l}\text { Minimum interval } \\
\text { between two } \\
\text { donations }\end{array}$} & Correct & 60 & 55 \\
\hline & & Incorrect & 49 & 45 \\
\hline & & Don't know & 0 & 0 \\
\hline \multirow{3}{*}{8} & \multirow{3}{*}{\begin{tabular}{|c|} 
Required \\
haemoglobin level to \\
donate blood
\end{tabular}} & Correct & 42 & 38.5 \\
\hline & & Incorrect & 62 & 56.9 \\
\hline & & Don't know & 5 & 4.6 \\
\hline \multirow{3}{*}{9} & \multirow{3}{*}{$\begin{array}{c}\text { Mandatory tests for } \\
\text { which donated blood } \\
\text { is screened for }\end{array}$} & Correct & 34 & 31.5 \\
\hline & & Incorrect & 58 & 53.7 \\
\hline & & Don't know & 17 & 15.7 \\
\hline & $\begin{array}{l}\text { Table } 2 . T \\
\text { donation }\end{array}$ & $\begin{array}{l}\text { owledge } \\
\text { g school }\end{array}$ & $\begin{array}{l}\text { ood } \\
\text { ers }\end{array}$ & \\
\hline
\end{tabular}

The attitude towards voluntary blood donation was evaluated by 4 questions and the responses were summarized in table $3.97 .2 \%$ felt that blood donation is painless and $96.3 \%$ said it is unethical to receive money for blood donation. The most common reason for not donating blood (53.3\%) is no one had asked them to donate. $23.3 \%$ felt that they are not fit to donate blood. Fear of needles was the reason in $11.1 \%$ of the respondents and $4.4 \%$ felt they did not think about blood donation at all. Other health reasons constituted $7.7 \%$ of nondonation. 


\begin{tabular}{|c|c|c|c|c|}
\hline $\begin{array}{l}\text { Sl. } \\
\text { No. }\end{array}$ & $\begin{array}{c}\text { Questions } \\
\text { Assessing the } \\
\text { Attitude on } \\
\text { Voluntary Blood } \\
\text { Donation } \\
\end{array}$ & Responses & $\begin{array}{c}\text { No. of } \\
\text { Respon- } \\
\text { dents }\end{array}$ & $\%$ \\
\hline \multirow{3}{*}{1} & \multirow{3}{*}{$\begin{array}{c}\text { Is blood donation } \\
\text { very painful? } \\
\text { Yes/No }\end{array}$} & Correct & 106 & 97.2 \\
\hline & & Incorrect & 3 & 2.8 \\
\hline & & Don't know & 0 & 0 \\
\hline \multirow[b]{2}{*}{2} & \multirow{2}{*}{$\begin{array}{c}\text { Will you get money } \\
\text { for voluntary blood } \\
\text { donation }\end{array}$} & Yes & 04 & 3.7 \\
\hline & & No & 105 & 96.3 \\
\hline \multirow{5}{*}{3} & \multirow{5}{*}{$\begin{array}{l}\text { Reason for not } \\
\text { donating blood }\end{array}$} & Fear of needles & 10 & 11.1 \\
\hline & & $\begin{array}{c}\text { I think, I am not fit } \\
\text { to donate blood }\end{array}$ & 21 & 23.3 \\
\hline & & $\begin{array}{c}\text { No one has asked } \\
\text { me to donate blood }\end{array}$ & 48 & 53.3 \\
\hline & & Didn't think of it & 04 & 4.4 \\
\hline & & Pre-existing illness & 07 & 7.7 \\
\hline \multirow{5}{*}{4} & \multirow{5}{*}{$\begin{array}{l}\text { What is the most } \\
\text { effective source of } \\
\text { knowledge on } \\
\text { voluntary blood } \\
\text { donation }\end{array}$} & \begin{tabular}{|c|} 
Mass media \\
(TV/Radio/Movie) \\
\end{tabular} & 105 & 96.3 \\
\hline & & $\begin{array}{c}\text { Electronic media } \\
\text { (Facebook \& } \\
\text { Twitter) }\end{array}$ & 23 & 21.1 \\
\hline & & \begin{tabular}{|c|} 
Printed articles \\
(Newspaper/books \\
/posters)
\end{tabular} & 88 & 80.7 \\
\hline & & People & 28 & 25.7 \\
\hline & & $\begin{array}{c}\text { Workshops/camps } \\
\text { /seminars }\end{array}$ & 68 & 62.4 \\
\hline
\end{tabular}

Table 3. The attitude towards voluntary donation of blood

The practice of the teachers on voluntary blood donation was tested by 4 questions and the responses were summarized in table $4.46 .8 \%$ teachers needed blood for their family and friends. However only $17.4 \%$ donated blood. $56.9 \%$ teachers motivated their students about voluntary blood donation. $81.7 \%$ were willing to donate blood in future and $96.3 \%$ assured to motivate their students on voluntary blood donation.

\begin{tabular}{|c|c|c|c|c|}
\hline $\begin{array}{r}\text { Sl. } \\
\text { No. }\end{array}$ & Questions & Response & \begin{tabular}{|c|} 
No. of \\
Respondents
\end{tabular} & $\%$ \\
\hline \multirow{2}{*}{1} & \multirow{2}{*}{$\begin{array}{c}\text { Have you ever needed } \\
\text { blood for } \\
\text { you/family/friends }\end{array}$} & Yes & 51 & 46.8 \\
\hline & & No & 58 & 53.2 \\
\hline \multirow{2}{*}{2} & \multirow{2}{*}{$\begin{array}{c}\text { Are you willing to } \\
\text { donate blood in future }\end{array}$} & yes & 89 & 81.7 \\
\hline & & No & 20 & 18.3 \\
\hline \multirow{2}{*}{3} & \multirow{2}{*}{$\begin{array}{c}\text { Have you ever } \\
\text { motivated your } \\
\text { students to donate } \\
\text { blood }\end{array}$} & Yes & 62 & 56.9 \\
\hline & & No & 47 & 43.1 \\
\hline \multirow{2}{*}{4} & \multirow{2}{*}{$\begin{array}{c}\text { Will you motivate your } \\
\text { students to donate } \\
\text { blood in the future }\end{array}$} & Yes & 105 & 96.3 \\
\hline & & No & 04 & 3.7 \\
\hline \multicolumn{5}{|c|}{$\begin{array}{l}\text { Table 4. The practice of blood } \\
\text { donation among school teachers }\end{array}$} \\
\hline
\end{tabular}

\section{DISCUSSION}

There are lots of studies available in the literature on the knowledge, attitude and practices on voluntary donation of blood among health care workers, college students, voluntary blood donors, high school students in various demographic profiles across the globe. However, there are no studied which assess the same on school teachers.

In our study, most of the teachers (82.6\%) never donated blood. Only 19 teachers who constituted around 17.4\% (18 female and one male) donated blood. In a similar study on health care workers in Nigeria, $22.1 \%$ donated $^{7}$ and $39 \%$ among health care staff in Gujarat have donated blood. ${ }^{8}$ In a study done in Karachi, ${ }^{9} 18 \%$ of the medical students and $27 \%$ of the non-medical students donated blood. $94.7 \%$ of the donors were first time donors in our study. However, studies done by Uma et al ${ }^{10}$ showed $46 \%$ were first time donors whereas Zaller et al ${ }^{11}$ study showed only $17.5 \%$ of the donors were first time donors. This clearly states that the practice of blood donation among teachers was very poor compared to other study groups. The most common blood group in our study is $\mathrm{O+ve}$ which is the most common blood group in South India. ${ }^{12}$

The knowledge on blood donation was assessed by a set of 9 questions. The overall knowledge percentage was $67.4 \%$. The respondents scored more than $70 \%$ on the general aspects of blood donation. Surprisingly the knowledge on the actual process of blood donation was also better than studies done on health care workers, ${ }^{7}$ medical students ${ }^{13}$ and the general public. ${ }^{10}$ The questions testing the actual process of blood donation were the volume of blood taken, required haemoglobin level and the minimum interval between two donations. Hence the teachers had a very good knowledge on blood donation.

The teachers had a positive attitude towards blood donation. $96.3 \%$ felt that blood donation is a voluntary process and the donors should not receive money for the same. The most common reason for not donating blood is no one has asked them to do so. The same fact has been highlighted by several studies as the most common reason for not donating blood.6,7,14 The second common reason is that they believed they are not fit to donate blood. Other reasons being the fear of needles, did not think about blood donation and other health issues. According to our study and other studies 15,16 the most effective medium for dissemination of knowledge on blood donation is mass media followed by printed articles such as newspapers and books. Hence advertisements and talk shows on blood donation can create awareness regarding voluntary blood donation.

The knowledge and attitude on blood donation when put into practice, the results are not satisfactory. Though $46.8 \%$ needed blood for their family and friends, only $17.4 \%$ donated blood and $43.1 \%$ teachers never motivated their students about blood donation. However, $96.3 \%$ teachers assured to motivate the students in future and $81.7 \%$ were willing to donate blood. These results are comparable to other studies.7,17 Hence the disparity between the knowledge, attitude and practice on blood donation could be due to the lack of opportunity 10 and communication gap between the blood banks and the school teachers.

\section{CONCLUSION}

This study revealed the secondary school teachers have more than adequate knowledge and attitude towards voluntary blood donation. However, practice on blood donation is very poor. 
This could be due to the lack of opportunity for blood donation and communication gap between the blood banks and the school teachers. Hence there must be a system to create opportunities for blood donation and measures to bridge the communication gap so that more donors would be volunteering to donate blood. Being teachers, they are the role model to the students. As the saying goes, 'Practice what you preach', if the teachers donate blood, the students will obviously come forward to donate blood.

\section{REFERENCES}

[1] Blood safety and availability. World Health Organization. Fact sheet No: 279, Geneva 2012.

[2] Shahshahani JH, Yavari MT, Attar M, et al. Knowledge, attitude and practice study about blood donation in the urban population of Yazd, Iran, 2004. Transfusion Medicine 2006;16(6):403-9.

[3] Sareen R, Gupta GN, Dutt A. Donor awareness: key to successful voluntary blood donation. F1000Research 2012;1:29.

[4] National blood policy. National AIDS Control Organization, Ministry of Health and Family Welfare, Government of India, New Delhi 2007.

[5] Voluntary blood donation programme. An operational guideline. National AIDS Control Organization, Ministry of Health and Family Welfare, Government of India, New Delhi 2007.

[6] Dubey A, Sonker A, Chaurasia R, et al. Knowledge, attitude and beliefs of people in North India regarding blood donation. Blood Transfusion 2014;12(Suppl1):s21-7.

[7] Benedict N, Usimenahon A, Alexander NI, et al. Knowledge, attitude and practice of voluntary blood donation among physicians in a tertiary health facility of a developing country. Journal of Blood Disorders \& Transfusion 2012.

[8] Mullah F. Study of knowledge, perceptions and practices related to blood donation among the healthcare support staff of a tertiary care hospital in Gujarat, India. Online Journal of Health and Allied Sciences 2013;12(1).
[9] Anwer MO, Fawwad SH, Anwer S, et al. Attitude toward blood donation among medical and nonmedical students across Karachi. Asian journal of transfusion science 2016;10(2):113-7.

[10] Zaller N, Nelson KE, Ness P, et al. Knowledge, attitude and practice survey regarding blood donation in a Northwestern Chinese city. Transfusion Medicine 2005;15(4):277-86.

[11] Salaudeen AG, Odeh E. Knowledge and behavior towards voluntary blood donation among students of a tertiary institution in Nigeria. Nigerian journal of clinical practice 2011;14(3):303-7.

[12] Das PK, Nair SC, Harris VK, et al. Distribution of ABO and Rh-D blood groups among blood donors in a tertiary care centre in South India. Tropical doctor 2001;31(1):47-8.

[13] Kowsalya V, Vijayakumar R, Chidambaram R, et al. A study on knowledge, attitude and practice regarding voluntary blood donation among medical students in Puducherry, India. Pakistan Journal of Biological Sciences. 2013;16(9):439.

[14] Ahmed Z, Zafar M, Khan AA, et al. Knowledge, attitude and practices about blood donation among undergraduate medical students in Karachi. Journal of Infectious Diseases and Therapy 2014.

[15] Chopra D, Jauhari N. Knowledge attitude \& practices towards voluntary blood donation among medical students in Barabanki. Indian Journal of Community Health 2015;27(3):386-90.

[16] Agrawal A, Tiwari AK, Ahuja A, et al. Knowledge, attitude and practices of people towards voluntary blood donation in Uttarakhand. Asian journal of transfusion science 2013;7(1):59-62.

[17] Bharatwaj RS, Vijaya K, Rajaram P. A descriptive study of knowledge, attitude and practice with regard to voluntary blood donation among medical undergraduate students in Pondicherry, India. Journal of clinical and diagnostic research 2012;6(4):602-4. 